Archimer, archive institutionnelle de l'ffremer Volume 445, Issue 1, 1 January 2006, Pages 56-64 http://www.ifremer.fr/docelec/

\title{
Fucoidan a sulfated polysaccharide from brown algae is a potent modulator of connective tissue proteolysis
}

\author{
Karim Senni ${ }^{\mathrm{a},{ }^{*}}$, Farida Gueniche ${ }^{\mathrm{a}}$, Alexandrine Foucault-Bertaud ${ }^{\mathrm{a}}$, Sylvie Igondjo-Tchen ${ }^{\mathrm{a}}$, Florence \\ Fioretti $^{\mathrm{a}}$, Sylvia Colliec-Jouault ${ }^{\mathrm{b}}$, Patrick Durand ${ }^{\mathrm{b}}$, Jean Guezennec ${ }^{\mathrm{b}}$, Gaston Godeau ${ }^{\mathrm{a},{ }^{* *}}$ and Didier \\ Letourneur ${ }^{\mathrm{c}}$
}

\author{
aUniversité Paris Descartes, Faculté de Chirurgie Dentaire, EA2496 Réparations et Remodelages \\ Oro-faciaux, Montrouge, France \\ ${ }^{\mathrm{b}}$ IFREMER Nantes/Brest Plouzané, France \\ 'INSERM U. 698, Universités Paris VII \& Paris XIII, CHU X. Bichat, Paris, France
}
Corresponding authors :
* senni k@yahoo.com
**godeau_g@yahoo.fr

\begin{abstract}
:
Fucoidans are sulfated fucosylated polymers from brown algae cell wall that exhibit some heparin/heparan sulfate properties. We previously demonstrated that these polysaccharides were able in vitro to stimulate dermal fibroblast proliferation and extracellular matrix deposition. Here, we investigated the action of a $16 \mathrm{kDa}$ fucoidan fraction on parameters involved in connective tissue breakdown. This fucoidan is able to inhibit gelatinase A secretion and stromelysin 1 induction by interleukin-1 $\beta$ on dermal fibroblasts in culture. Furthermore, we observed that fucoidan increases the rate of association of MMPs with their specific inhibitors namely TIMPs. Using tissue sections of human skin in ex vivo experiments, we evidenced that this polysaccharide was able to minimize human leukocyte elastase activity resulting in the protection of human skin elastic fiber network against the enzymatic proteolysis due to this serine proteinase. These results suggested that fucoidan could be used for treating some inflammatory pathologies in which uncontrolled extracellular matrix degradation takes place.
\end{abstract}

Keywords: Fucoidan; Glycosaminoglycans; Extracellular matrix remodeling; Matrix metalloproteinases; Leukocyte elastase; Interleukin-1ß 


\section{Introduction}

Connective tissue destruction during inflammatory diseases such as chronic wound, chronic leg ulcers, periodontitis or rheumatoid arthritis, is the result of continuous supply of inflammatory cells and exacerbated production of inflammatory cytokines and matrix proteinases. At the site of injury, the over-secretion of inflammatory cytokines such as Interleukin-1 beta (IL-1 $\beta$ ) triggers the uncontrolled expression of matrix metalloproteinases (MMPs) by leukocytes and resident mesenchymal, epithelial or endothelial cells. These MMPs are a class of neutral zinc-metalloendopeptidases degrading matrix macromolecules and numerous other components such as growth factors, proteinases, and plasma proteins [1]. Therefore MMPs have been implicated in tissue remodeling during physiologic processes such as embryogenesis, growth and wound healing, but unusual location, over-expression or alteration of their activity can be deleterious in pathological states among which cancer, atherosclerosis, fibrosis and chronic inflammation. These proteinases also called matrixin are divided into subfamilies, according to their substrate specificity, cell location and primary structure. Matrixin subfamilies include gelatinases (MMP-2, MMP-9), collagenases (MMP-1, 8 and 13), stromelysins (MMP-3, 10 and 11) and cell membrane type MMPs (MT1-MMP to MT6-MMP) [1,2]. MMPs are regulated at different levels, and except for MMP-11 and MTMMPs, are secreted in inactive proforms (zymogens), so proMMPs are activated by many proteinases, able to cleave the pro-domain, such as MMPs themselves and serine proteinases, like leukocyte elastase and plasmin [3]. A specific class of endogenous inhibitors named TIMPs for tissue inhibitor of metalloproteinases bind strongly MMPs to regulate their activities. A disturbed balance between MMPs and their specific tissue inhibitors has been described in different inflammatory diseases and led to uncontrolled degradation of extracellular components. 
Among extracellular matrix components heparin/heparan sulfates and other glycosaminoglycans (GAGs) were shown to exhibit multiple biological activities such as growth factor promotion [4], matrix macromolecules structuring [5-8], inhibition of leukocyte margination and proteolysis control [9-11]. These components were proposed to lessen the enzymatic degradation of the extracellular matrix during inflammatory states. Unfortunately, the mammalian origin of these compounds and the potent anti-thrombotic activity of some members (heparin) limit their use for the prevention or the treatment of inflammatory diseases.

Several classes of non-animal polysaccharides, for example dextran derivatives $[12,13]$ pentosan sulfate [14] and fucoidans $[15,16]$ exhibit heparin biomimetic properties. Among them, fractionated fucoidans $(<30 \mathrm{kDa})$ extracted from pheophycae cell wall from which the structure was defined [17] exhibit anti-thrombotic activity but have a weak bleeding effect [18]. Moreover, these fucoidans have some anti-inflammatory properties such as anticomplementary activities [19] and inhibition of leukocyte margination [20]. These polysaccharides can also promote FGF-2 activities [16], inhibit smooth muscle cell proliferation [15], promote dermal fibroblast proliferation and accelerate collagen processing by cultured fibroblasts and smooth muscle cells [21,22], and potentiate in vivo the neoangiogenesis in a rat critical limb ischemia model [23]. Recently, the in vivo effects of fucoidan have also been reported in the prevention of rabbit restenosis after stent implantation [24].

The purpose of this study was to investigate the capability of a $16 \mathrm{kDa}$ fraction of fucoidan to interfere with factors involved in connective tissue degradation such as matrix metalloproteinases secretion, MMPs/TIMPs association and leukocyte elastase activity. We demonstrated that fucoidan was able to decrease gelatinase A (MMP-2) and stromelysin-1 (MMP-3) secretion by cultured human dermal fibroblasts in the presence or absence of IL-1 $\beta$. 
Using human skin tissue sections, we evidenced the ability of fucoidan to inhibit human leukocyte elastase (HLE) activity and to protect dermal elastic fiber network against ex vivo proteolysis induced by HLE.

\section{Experimental Procedures}

\subsection{Materials}

Fucoidan fraction from "Institut Français de Recherche pour l'Exploitation de la Mer" (IFREMER) was prepared in accordance with Colliec-Jouault et al. [25]. Fucoidan was extracted from the brown algae A. nodosum after fragmentation by acidic hydrolysis and fractionated by gel filtration. The chromatographic molecular weight of the fucoidan fraction was $16 \mathrm{kDa}$ as determined by high performance exclusion chromatography. The L-fucose, uronic acid and sulfate contents of fucoidan were determined by colorimetric assays to be $55.7 \%, 6.3$, and $29 \%$ respectively.

Media for cell culture was obtained from Sigma, and fetal calf serum and IL$1 \beta$ (50000 units/ml) from Boehringer Mannheim (Mannheim, Germany). Human leukocyte elastase $(875 \mathrm{U} / \mathrm{mg}$ of proteins) was purchased from Elastin Product Company (EPC, Missoury, USA) and human MMP-2 ELISA test (Quantikine $\left.{ }^{\circledR}\right)$ from R\&D systems (Minneapolis USA).

\subsection{Dermal fibroblasts culture}

Human dermal fibroblasts were obtained from prepuces of healthy subjects aged 3-4 and for one cell strain after breast plastic surgery of a mid aged patient. Patients' parents and patient with breast surgery gave their informed consent for biopsies according to the Helsinki declaration. Tissues were rinsed three times with Dulbecco's Modified Eagle's medium (DMEM; Gibco; Paisley, UK) containing 400IU/mL of penicillin, $400 \mu \mathrm{g} / \mathrm{mL}$ of streptomycin 
and $4 \mu \mathrm{g} / \mathrm{mL}$ of amphoterycin B and cut into small pieces. Explants were deposited in $25 \mathrm{~cm}^{2}$ culture flask and incubated in a humidified atmosphere of $5 \% \mathrm{CO}_{2}$, in DMEM supplemented with $20 \%$ fetal calf serum (FCS), $100 \mathrm{IU} / \mathrm{mL}$ penicillin, $100 \mu \mathrm{g} / \mathrm{mL}$ streptomycin and $2 \mu \mathrm{g} / \mathrm{ml}$ amphoterycin B. In these conditions fibroblasts leave the explant in 3 to 5 days and settle the entire flask surface in 3 weeks. Fibroblasts were grown in complete medium (complete medium: DMEM, 10\% FCS, $100 \mu \mathrm{g} / \mathrm{mL}$ streptomycin and $100 \mathrm{IU} / \mathrm{mL}$ penicillin) and subcultured weekly by incubation at $37^{\circ} \mathrm{C}$ for 2 min with Trypsin-EDTA (Gibco) followed by addition of complete medium washing and re-suspension in fresh medium.

For supernatant MMP studies, fibroblasts (5 or 6 passages) were grown in complete medium, in 24 well plates until confluence. Complete media were then removed and cells were rinsed twice with PBS. Cells were incubated for $48 \mathrm{~h}$ with serum free media alone (control), after pre-treatment with IL-1 $\beta(100 \mathrm{U} / \mathrm{ml})$ for $90 \mathrm{~min}$ (control of IL-1 $\beta$ pre-treatment experiments) or with continuous incubation with $\mathrm{IL}-1 \beta(100 \mathrm{U} / \mathrm{ml})$ (control of continuous treatment). Fucoidan at 10 and $100 \mu \mathrm{g} / \mathrm{ml}$ was added for 48 hours in serum free media, after IL-1 $\beta$ pre-treatment or during the IL- $1 \beta$ continuous treatment.

\subsection{Zymographic analysis}

Gelatinolytic activities present in cell culture supernatant were identified by gelatin zymography using SDS-PAGE containing $1 \mathrm{mg} / \mathrm{ml}$ type I porcine gelatin (Sigma) : 10\% Duracryl/bis acrylamide 30/8 from Millipore, $1.5 \mathrm{M}$ Tris- $\mathrm{HCl} \mathrm{pH}$ 8,8; $100 \mu 1$ SDS 10\%, and 4 $\mathrm{ml}$ of distilled water $\mathrm{pH} 8.8$, stacking gel contained $4 \%$ polyacrylamide in $0.125 \mathrm{M}$ Tris, $\mathrm{pH}$ 6.8. Each gel was polymerized by adding $50 \mu 1$ of $10 \%$ ammonium persulfate and $10 \mu \mathrm{L}$ of 0,1\% Temed. HT1080 cell line media was used as standard. This established cell line expressed constitutively pro-gelatinase $\mathrm{A}(72 \mathrm{kDa})$ and pro-gelatinase $\mathrm{B}(92 \mathrm{kDa})$ in the

culture medium. Protein molecular standards were purchased from Bio-Rad (Hercules, CA). 
Samples were half diluted with SDS-non-reducing sample buffer $(250 \mathrm{mM}$ Tris $\mathrm{pH} 6.8,50 \%$ glycerol $0.4 \%$ bromophenol blue, and SDS 10\%) and separated. After electrophoresis, gels were soaked in $2.5 \%$ Triton X 100 for $2 \times 30$ min, and incubated with $100 \mathrm{mM}$ Tris- $\mathrm{HCl}(\mathrm{pH}$ 7.4) containing, $30 \mathrm{mM} \mathrm{CaCl}_{2}, 0.1 \mu \mathrm{M} \mathrm{ZnCl}_{2}$, and $0.0015 \%$ Brij-35 at $37^{\circ} \mathrm{C}$ for $19 \mathrm{~h}$. Gels were subsequently stained with $0.5 \%$ Coomassie brilliant blue R-250, and the location of gelatinolytic activity was detected as clear bands in the background of uniform staining. The use of HT1080 supernatant for external standard in each gel allowed comparison of gelatinolytic activities detected on different gels.

\subsection{Western blotting analysis of MMP-2, MMP-3, TIMP-1 and TIMP-2}

Samples were mixed with non-reducing sample buffer. As for zymographic analysis, gels were run under Laemmli conditions at $80 \mathrm{~V}$, for $15 \mathrm{mn}$ and then $160 \mathrm{~V}$ for $1 \mathrm{~h} 30$. Proteins were transferred onto a polyvinylidene fluoride membrane (PVDF, from Millipore) at $80 \mathrm{~V}$ for 1h. Non-specific binding sites were blocked for $1 \mathrm{~h}$ (non-fat milk $5 \%, 0.05 \%$ Tween20 in PBS) and washed in PBS $(4 \times 15 \mathrm{~min})$. The membrane was incubated for 1 night at $4{ }^{\circ} \mathrm{C}$ with a monoclonal primary antibody directed against human MMPs or TIMPs (Calbiochem France, dilution 1/500 in PBS), washed, then incubated with an appropriate HRP secondary antibody (Sigma, dilution 1/750 in PBS). Peroxidase activity was detected by chemiluminescence.

\subsection{Enzymisation experiments}

Experimental procedures were performed on frozen human skin serial tissue sections ( $8 \mu \mathrm{m}$ thick and 6 sections per conditions).

\subsubsection{Ex vivo HLE inhibition assay}

Solutions with $10 \mu \mathrm{L}$ of incubation buffer $(100 \mathrm{mM}$ Tris/HCl, $\mathrm{pH} 8)$ containing human leukocyte elastase $(2 \mu \mathrm{g}$ or $5 \mu \mathrm{g})$ with or without fucoidan $(1,10$ or $100 \mu \mathrm{g} / \mathrm{ml})$ were incubated 
for $30 \mathrm{~min}$ at $37^{\circ} \mathrm{C}$. After this incubation, solutions were laid onto tissue sections (control: incubation buffer alone) and placed for three hours in a humidified chamber at $37^{\circ} \mathrm{C}$. The addition of an excess of cold incubation buffer stopped the reaction.

\subsubsection{Ex vivo skin elastic network protection assay}

Solutions of incubation buffer $(10 \mu \mathrm{l})$ alone or containing fucoidan $(1,10$ or $100 \mu \mathrm{g} / \mathrm{ml})$ were laid onto sections for $30 \mathrm{~min}$ at $37^{\circ} \mathrm{C}$. The slides were rinsed with incubation buffer and then incubated with $10 \mu \mathrm{l}$ of Tris buffer containing $2 \mu \mathrm{g}$ or $5 \mu \mathrm{g}$ of human leukocyte elastase (control: incubation buffer alone). Reaction was stopped as mentioned above.

\subsection{Elastic network staining}

The sections were specifically stained with the polyphenolic dye, $(+)$ catechin Fuchsin as previously described by [26]. Elastic fibers appeared in deep blue black, while the background was poorly stained. This allowed further quantitative estimation of the area fractions occupied by these fibers by automated image analysis [26].

\subsection{Automated image analysis}

Computerized analysis of skin elastic fibers was carried out as previously described $[27,28]$. The analysis was performed directly on the histological sections observed under a Zeiss standard microscope with a video camera (Sophretec, Bezons, France). Black and white images generated by the video camera were converted into 256 grey levels using a Sophretec MVM 600 image Memory, then transferred to a BFM 186 microcomputer (Sophretec) and analyzed using mathematical morphology software [29] The area fraction occupied by the skin elastic fibers $(\mathrm{AA} \%)$ was determined automatically and represents the surface occupied by the skin elastic fibers in relation with the total tissue area analyzed. 


\subsection{Statistical analysis}

For zymographic and ex-vivo HLE inhibition experiments, data were compared using non parametric test (Kruskal-Wallis test followed if significant by group comparison with the Mann-Whitney U test). Differences were considered significant if $p \leq 0.05$. Results are given as means $\pm \mathrm{SEM}$.

\section{Results}

\subsection{Fucoidan inhibits proMMP-2 (gelatinase A) secretion}

Human dermal fibroblasts express $72 \mathrm{kDa}$ gelatinolytic activity corresponding to proMMP-2 (pro-gelatinase A), as shown by a lysis band present on gelatin zymograms (Fig. 1a and b upper part), and specific signal evidenced by western blotting (Fig. 1a and Fig. 1b, bottom part). ProMMP-2 activities were quantified and referred to gelatinolytic activities of media from HT 1080 cell line used as external reference. Mean results obtained for six human fibroblast strains were presented in Figure 1c. The results evidenced a decrease of proMMP-2 in culture media with cells incubated with fucoidan. Quantifications in Figure 1c showed, in absence of IL-1 $\beta$, a decrease of 35\% $(\mathrm{p}<0.001)$ and $45 \%(\mathrm{p}<0.0001)$ of $72 \mathrm{kDa}$ gelatinolytic activities with 10 and $100 \mu \mathrm{g} / \mathrm{ml}$ of fucoidan respectively (Fig. 1a lane 3 and 4).

No significant effect on proMMP-2 secretion could be observed after IL-1 $\beta$ pretreatment for 90 minutes, but continuous IL-1 $\beta$ incubation for 48 hours induced a slight but significant increase $(\mathrm{p}<0.05 ;+27 \%)$ of proMMP-2 secreted in the culture media (Figure $1 \mathrm{c})$. Fucoidan at $10 \mu \mathrm{g} / \mathrm{ml}$ was able to decrease of about $20 \%$ proMMP-2 secretion submitted to both IL-1 $\beta$ treatments (Fig. 1a lane 5 and Fig. $1 \mathrm{~b}$ lane 3). Fucoidan at $100 \mu \mathrm{g} / \mathrm{mL}$ induced an important decrease $(p<0.0001)$ when compared with the respective IL- $1 \beta$ controls $(-49 \%$ for pre-treatment experiments and $-51 \%$ for continuous incubation experiments; Fig. 1c). We also 
investigated by ELISA the effect of fucoidan on total MMP-2 secretion by dermal fibroblasts in culture. We found that fucoidan significantly decreased gelatinase A secretion at $10 \mu \mathrm{g} / \mathrm{ml}$ $\left(4.22 \mathrm{ng} / 10^{5}\right.$ cells; $\left.\mathrm{p}<0.01\right)$ and $100 \mu \mathrm{g} / \mathrm{ml}\left(7.02 \mathrm{ng} / 10^{5}\right.$ cells $\left.\mathrm{p}<0.05\right)$ when compared with control $\left(21.6 \mathrm{ng} / 10^{5}\right.$ cells $)$.

\subsection{Fucoidan inhibits proMMP-3 (stromelysin-1) induction by IL-1ß}

As for control culture (Fig. 2a lane 1 and Fig. 2b lane 1), dermal fibroblasts incubated with fucoidan gave no significant increase of proMMP-3 $(57 \mathrm{kDa})$ observed by western blotting (Fig. 2a lane 3 and 4). IL-1 $\beta$ added in culture media led to a strong proMMP-3 secretion by dermal fibroblasts in culture (Fig. 2a and b, lane 2). ProMMP-3 induction by IL$1 \beta$ pre-treatment decreased for three different strains of 38 to $44 \%$ when fucoidan (10 and $100 \mu \mathrm{g} / \mathrm{ml}$ ) was added to cell culture media (Fig. 2a). ProMMP-3 induction by continuous IL$1 \beta$ incubation decreased of 39 to $50 \%$ when fucoidan $(10$ and $100 \mu \mathrm{g} / \mathrm{ml})$ was added (Fig. $2 \mathrm{~b})$. We could also observed a specific MMP-3 high molecular weight complex of $>100 \mathrm{kDa}$ (Fig. 2a).

\subsection{Fucoidan increased TIMPs and MMPs complex formation}

Free MMP-2, free TIMP-1, and their respective complex forms can be detected by western blotting (Fig. 3a, 3b, 4a). After quantification of western blots with an internal standard in each gel and normalization for $10^{3}$ cells, the effectiveness of complex formation was calculated, as the ratio between signal values of high molecular complexes and respective signal values of free forms (72kDa for proMMP-2, and 29kDa for TIMP-1; Fig. 3c, 4b).

Gelatinase A MMP 2 complex formation was enhanced when fucoidan was added to cell culture media (Fig. 3c). Whatever cell treatments (without IL-1 $\beta$, IL-1 $\beta$ pre-treatment or continuous incubation with IL-1 $\beta$ ), an increase in MMP-2 complex formation was observed with fucoidan ( 2 and 3.5 fold increase with $10 \mu \mathrm{g} / \mathrm{ml}$ and $100 \mu \mathrm{g} / \mathrm{ml}$ of fucoidan, respectively). 
As shown for proMMP-2, fucoidan reduced secreted free TIMP-1 (29kDa) (Fig. 4a and $4 \mathrm{~b}$ ). We also observed $100 \mathrm{kDa}$ and 220kDa TIMP-1 complexes (Fig. 4a). TIMP-1 complex at $100 \mathrm{kDa}$ was increased when fucoidan was added in cell culture (Fig. 4b).

\subsection{Fucoidan inhibits human dermal elastic network degradation by human leukocyte elastase}

We previously demonstrated in vitro the ability of fucoidan to inhibit synthetic substrate degradation by human leukocyte elastase, HLE [22]. With an ex-vivo approach, we investigated here qualitatively and quantitatively the effect of fucoidan on the degradation of the HLE natural substrate, skin elastic fibers.

In human mid dermal control sections (Fig. 5a), the skin elastic network consists of oxytalan fibers appearing as thin fibers perpendicular to the epithelium, linked to elaunin fibers and, of thick and well positioned elastic fibers localized in mid dermis. On HLE $(5 \mu \mathrm{g})$ enzymized skin tissue sections (Fig. 5b) degraded elastic fibers were evidenced as well as epithelium detachment. In presence of fucoidan, HLE was unable to degrade elastic fibers (Fig. 5c, 5d). Skin sections with fucoidan and HLE (Fig. 5c, 5d) evidenced intact dermalepidermal junction and a skin elastic fiber network comparable to that observed in control skin sections.

The effect on skin elastic fibers was also observed on vascular elastic lamellae (Fig. 5e, f, g, h). Vascular elastic network consists of concentric lamellae structures as observed on mid dermal arteriole on control skin section (Fig. 5e). Skin sections receiving $2 \mu$ g HLE demonstrated a complete disappearance of vascular elastic lamellae (Fig. 5f). Few elastic components can already be observed when HLE was incubated with a low concentration $(1 \mu \mathrm{g} / \mathrm{ml})$ of fucoidan (Fig. $5 \mathrm{~g})$. Fucoidan at $100 \mu \mathrm{g} / \mathrm{ml}$ strongly inhibits the degradation induced by HLE as documented on Figure 5h. 
Image analysis allowed quantitative estimation of elastic network hydrolysis. Area fractions (AA\%) occupied by dermal elastic fiber network are shown in Figure 6. Elastic fiber $\mathrm{AA} \%$ of the control sections are estimated at $7.5 \pm 1.5 \%$. Enzymized skin tissue sections gave $\mathrm{AA} \%$ of $4.18 \%(\mathrm{p}<0.01 ; 45 \%$ of hydrolysis $)$ with $2 \mu \mathrm{g}$ HLE, and $0.79 \%(\mathrm{p}<0.001 ; 90 \%$ of hydrolysis) with $5 \mu \mathrm{g}$ HLE (Fig. 5). Incubation of HLE with fucoidan strongly decreases hydrolysis of elastic fibers (Fig. 6). Fucoidan at $1 \mu \mathrm{g} / \mathrm{ml}$ reduced hydrolysis (51\% vs $90 \%$ with $5 \mu \mathrm{g}$ ELH alone; $20 \%$ vs $45 \%$ with $2 \mu \mathrm{g}$ of HLE alone). By incubation with $100 \mu \mathrm{g} / \mathrm{ml}$ of fucoidan, the appearance of elastic fibers with HLE incubation did not significantly differ from non-degraded elastic fibers. Quantification with $100 \mu \mathrm{g} / \mathrm{ml}$ of fucoidan evidenced only $13 \%$ and $23 \%$ hydrolysis in presence of $2 \mu \mathrm{g}$ and $5 \mu \mathrm{g}$ of HLE, respectively.

\subsection{Fucoidan protects dermal elastic fibers against human leukocyte elastase hydrolysis}

To investigate fucoidan protection of elastic fibers, skin sections were pre-incubated with fucoidan or in saline buffer (control) for 30 minutes, rinsed and then incubated with $2 \mu \mathrm{g}$ of HLE. Histological documents are reported in Figure 7. Control skin sections exhibited a classic dermal elastic fiber network structure with oxytalan, elaunin and elastic fibers $(\mathrm{AA} \%=$ 8.2\%; Fig. 7a). Dermal elastic fibers of enzymized sections were largely hydrolyzed (AA\%= 1.4\%; Fig. 7b). By pre-incubation with fucoidan at $10 \mu \mathrm{g} / \mathrm{ml}$ (Fig. 7c), elastic fibers were fragmented but good preservation of the global elastic fiber network was evidenced $(\mathrm{AA} \%=$ 4.33\%). Pre-incubation of skin sections with fucoidan at $100 \mu \mathrm{g} / \mathrm{ml}$ completely prevented skin elastic network degradation (AA\%=8.4\%; Fig. $7 \mathrm{~d})$.

\section{Discussion}

Maintenance of the equilibrium between deposition and degradation of extracellular matrix is essential to tissue homeostasis. In some pathological states, such as chronic inflammation, 
tissue degradation is increased, and matrix metalloproteinases, their endogenous inhibitors (TIMPs) and serine proteinases are involved in this imbalance. Sulfated glycosaminoglycans can modulate tissue remodeling to favor matrix macromolecules structuring [5,30], potentiate growth factors [4], and inhibit proteolysis [9,10,31]. Fucoidans are sulfated polysaccharides from brown algae cell wall which are described after fragmentation to mimic some heparin properties $[15,19,22]$. For example, fucoidan fractions promote FGF or VEGF activities $[16,23]$. Unlike fractionated species, crude fucoidans or over sulfated crude fucoidans are known to inhibit by sequestration heparin binding growth factors in vivo [32]. Sulfate content and molecular weight influence biological effects of fucoidan species.

In this work we investigated the effects of $16 \mathrm{kDa}$ fucoidan fraction on extracellular matrix degradation of human skin.

First, we demonstrated that this fucoidan in the presence or absence of IL-1 $\beta$, an inflammatory cytokine, decreased pro-gelatinase A (proMMP-2) and pro-stromelysin 1 (proMMP-3) secretion by cultured human dermal fibroblasts. Decrease in gelatinase A and stromelysin 1 zymogens was neither accompanied by an effect on the active form of MMP-2 and MMP-3 nor a decrease in total extracellular protein synthesis (data not shown).

Free form of TIMP-1, and proMMP-2 decreased in the presence of fucoidan. This decrease was associated with an increase of high molecular weight complex formation with and without IL-1 $\beta$ added in the culture medium. Similar effects on TIMP-1 and TIMP-2 complex were reported by Morvan et al. [33], who tested carboxymethyl sulfated dextran on mucositis model induced in hamster. Using kinetic methods, Butler et al. [34] evidenced the ability of heparin to enhance the rate of association of TIMP-3 but also TIMP-1 with matrix metalloproteinases particularly gelatinase A. As for other anionic polysaccharides we could suggest that fucoidan enhanced complex formation between gelatinase A and TIMP-1 or between stromelysin 1 and TIMP-1 but we can not excluded enhanced interactions between 
TIMP-1 and an other MMP, or between gelatinase A and an other TIMP, like TIMP-3 which exhibit heparin binding properties [11]. So Butler et al (1999) These authørs suggested that the increasing association between TIMPs and MMPs was due to interactions that depend on 3D-structure and charge densities of sulfated polysaccharides, such as those found in heparin, but also in derivatized dextrans and fucoidans.

We have also shown that fucoidan was able to decrease proMMP-3 induction by IL1 $\beta$. In our experiments, we have not been able to detect any basal expression of proMMP-3 $(57 \mathrm{kDa})$ by control dermal fibroblasts, but pre-treatment or continuous incubation with IL-1 $\beta$ potently induces its expression in cell supernatant. The induction of stromelysin 1 by IL-1 $\beta$ has been largely reported $[34,35,10]$. It has been reported that heparin and over-sulfated chondroitin sulfate had the capability to inhibit MMP-1 and MMP-3 protein and mRNA expression induced by IL-1 $\beta$ in mesangial cells [37], gingival fibroblasts [10], chondrocytes [38] and by phorbol ester for smooth muscle cells [39]. Within fibroblasts in culture, IL-1 $\beta$ receptors are mainly located to focal adhesion sites [40] and fibronectin involvement following cell surface heparan sulfate proteoglycan recruitment was shown to be necessary for IL- $\beta$ signal $[41,42]$. Furthermore, Vallés et al. [42] showed that addition of soluble heparin in media of cultured fibroblast inhibits IL-1 $\beta$ signal presumably by disturbing interactions between fibronectin and cell surface heparan sulfate proteoglycan. Interestingly, fucoidan as heparin favored retention of the newly synthesized fibronectin within extracellular matrix $[44,45]$. Thus, inhibition of MMP-3 induction by IL-1 $\beta$ in the presence of fucoidan could be caused in part, a similar mechanism in human dermal cells.

Human leukocyte elastase (HLE) is a serine proteinase that possesses a broad substrate specificity and can act by itself or in association with cathepsin $G$ to destroy tissue elastic fiber network [28]. This enzyme also contributes to tissue breakdown by the activation of many MMPs [45-47]. In pathological inflammation, HLE production and activity are 
exacerbated and induced deleterious pro-inflammatory factors [48,49]. As previously described, polyanionic polysaccharides like bacterial polysaccharides [49], sulfated glycosaminoglycans $[9,51]$ or derivatized dextrans [52] are inhibitors of HLE in vitro. We previously observed that fucoidan inhibited HLE synthetic substrate degradation [22]. We have investigated here whether fucoidan has the capacity to inhibit HLE and/or to protect human dermal elastic fibers, ie oxytalan, elaunin and elastic fibers, against proteolytic degradation. We determined by automated image analysis after specific staining [27], the level of elastic fibers within skin sections. Image analysis was previously found fairly accurate and correlated with the desmosine content determined by radioimmunoassay [53]. Such an ex vivo assay for the elastolytic capacity of endopeptidases provides more relevant information than an in vitro assay using synthetic substrate or purified elastin because elastic fibers are embedded within other macromolecular components in the skin, as glycoproteins or proteoglycans [54] which may affect elastolysis. In this work, dermal elastic fibers were sensitive to degradation by HLE, as reported earlier [28,55]. After incubation with fucoidan, elastolytic abilities of HLE solutions were decreased. Inhibitory sensitivity of leukocyte elastase by fucoidan may be due to the structural feature and the primary sequence of HLE. HLE is a basic protein, containing clusters of 18 arginine residues. Location of these cationic residues causes strong interactions with glycosaminoglycans, which explains the inhibitory effect of polyanionic compounds $[9,51,56]$. Fucoidan, a branched sulfated L-fucosyl polymer [17], may present optimal anionic charge density and 3D structure able to develop specific interactions with HLE, and subsequently induced an important HLE inhibition. Pre-incubation of skin sections with fucoidan before enzymatic digestion protects the skin elastic fiber network against HLE action. This protective effect also strongly suggested interactions between fucoidan and elastic fiber glycoproteins such as fribrillins, that required further detailed characterizations. 
In addition to the anti-complementary activities, leukocyte margination inhibition and potentiation of growth factors by fractionated fucoidan $[16,19,20]$, we evidenced here that these fucoidans were able to control important parameters involved in connective tissue destruction in human skin. Moreover, their weak bleeding effect [18] and non-animal origin is in favor of their use in clinic for humans. These properties suggested that fucoidan could treat some inflammatory pathologies such as chronic leg ulcer, emphysema or periodontitis in which uncontrolled extracellular matrix degradation takes place.

\section{References}

[1] Stamenkovic I. J. Pathol. 200 (2003) 448-464.

[2] Nagase H, Woessner JF Jr. J. Biol. Chem. 274 (1999) 21491-2194.

[3] Nagase H. Biol Chem. 378 (1997) 151-160.

[4] Yayon A, Klagsbrun M, Esko JD, Leder P, Ornitz DM. Cell. 64 (1991) 841-848.

[5] Mc Pherson JM, Sawamura SJ, Condell RA, Rhee W, Wallace DG. Collagen. Rel. Res. 8 (1988) 65-82.

[6] Scott JE. J. Anat. 1990;169: 23-35.

[7] Chung CY, Erickson HP. J Cell Sci. 110 (1997) 1413-1419.

[8] Wu WJ, Vrhovski B, Weiss AS. J. Biol. Chem. 274 (1997) 21719-21724.

[9] Volpi N. Biochim. Biophys. Acta.1290 (1996) 299-307.

[10] Gogly B, Dridi M, Hornebeck W, Bonnefoix M, Godeau G, Pellat B. Cell. Biol. Int. 23 (1999) 203-209.

[11] Yu WH, Woessner JF. J. Biol. Chem. 276 (2000) 4183-4191. 
[12] Senni K, Bochiellini C, Duchesnay A, Pellat B, Letourneur D, Kern P. J. Biomed Mater. Res. 40 (1998) 164-169.

[13] Logeart-Avramoglou D, Jozefonvicz J. J. Biomed. Mater Res. 48 (1999) 578-90.

[14] Klein-Soyer C, Beretz A, Cazenave JP, Wittendorp-Rechenmann E, Vonesch JL, Rechenmann RV, Driot F., Maffrand J.P. Arteriosclerosis. 9 (1989) 147-153.

[15] Logeart D, Prigent-Richard S, Jozefonvicz J, Letourneur D. Eur. J. cell. Biol. 74 (1997) 376-384.

[16] Matou S, Helley D, Chabut D, Bros A, Fischer AM. Thromb Res. 106 (2002) 213-221.

[17] Chevolot L, Foucault A, Chaubet F, Kervarec N, Sinquin C, Fisher AM. Carbohydr. Res. 319 (1999) 154-165.

[18] Millet J, Jouault SC, Mauray S, Theveniaux J, Sternberg C, Boisson Vidal C, Fischer A.M. 81 (1999) 391-395.

[19] Blondin C, Chaubet F, Nardella A, Sinquin C, Jozefonvicz J. Biomaterials. 17 (1996) 597-603.

[20] Van Osselaer N, Rampart M, Herman AG. Mediators inflamm. 5 (1996) 346-357.

[21] Logeart D, Letourneur D, Jozefonvicz J, Kern P. J. Biomater. Res. 30 (1996) 501-508.

[22] Senni K, Pellat B, Gogly B, Blondin C, Jozefonvicz J, Letourneur D, Colliec-Jouault S., Durand P, Sinquin C European Patent (2003) 1039916 (WO9932099).

[23] Luyt CE, Meddahi-Pelle A, Ho-Tin-Noe B, Colliec-Jouault S, Guezennec J, Louedec L, Prats H., Jacob M.P., Osborne-Pellegrin M., Letourneur D. J Pharmacol Exp Ther. 305 (2003) 24-30.

[24] Deux JF, Meddahi-Pelle A, Le Blanche AF, Feldman LJ, Colliec-Jouault S, Bree F, Boudghene F., Michel J.B., Letourneur D. Arterioscler Thromb Vasc Biol 22 (2002) 16041609. 
[25] Colliec S, Boisson-Vidal C, Jozefonvicz J. Phytochemistry 35 (1994) 697-700.

[26] Godeau G. Pathol Biol 32 (1984) 215-216.

[27] Godeau G, Gonnord G, Jolivet O, Schoevaert D, Pompidou A, Lagrue G, Robert A.M. Anal Quant Cytol Histol. 8 (1986) 321-325.

[28] Boudier C, Godeau G, Hornebeck W, Robert L, Bieth JG. Am J Respir Cell Mol Biol. 4 (1989) 497-503.

[29] Serra J. Image analysis and mathematical morphology. Academic Press London, 1982.

[30] Buczek-Thomas JA, Chu CL, Rich CB, Stone PJ, Foster JA, Nugent MA. J Cell Physiol. 192 (2002) 294-303.

[31] Rao NV, Kennedy TP, Rao G, Ky N, Hoidal J.R. Am Rev Respir Dis 142 (1990) 407412.

[32] Koyanagi S, Tanigawa N, Nakagawa H, Soeda S, Shimeno H. Biochem Pharmacol 65 (2003) 173-179.

[33] Morvan FO, Baroukh B, Ledoux D, Caruelle JP, Barritault D, Godeau G, Saffar JL. Am. J. Pathol. 164 (2004) 739-746.

[34] Butler GS, Apte SS, Willenbrock F, Murphy G. J Biol Chem. 274 (1999) 10846-10851.

[35] Quinones S, Saus J, Otani Y, Harris ED Jr, Kurkinen M. J Biol Chem. 264 (1989) 83398344.

[36] Mac Naul KL, Chartrain N, Lark M, Tocci MJ, Hutchinson NI. J Biol Chem 265 (1990) $17238-41725$.

[37] Kitamura M, Maruyama N, Mitarai T, Nagasawa R, Yokoo T, Sakai O. Biochem Biophys Res, 203 (1994) 1333-1338.

[38] Sadowski T, Steinmeyer J. Biochem Pharmacol 64 (2002) 217-227.

[39] Kenagy R.D, Nikkari ST, Welgus HG, Clowes AW. J Clin Invest 93 (1994) 1987-1993. 
[40] Qwarnstrom EE, MacFarlane SA, Page RC, Dower SK. Proc Natl Acad Sci. USA. 88 (1991) 1232-1236.

[41] Ostberg CO, Zhu P, Wight TN, Qwarnstrom EE. FEBS Lett. 367 (1995) 93-97.

[42] Valles S, Tsoi C, Huang WY, Wyllie D, Carlotti F, Askari JA, Humphries M.J., Dower S.K., Qwarnstrom E.E. J Biol Chem 274 (1999) 20103-20109.

[43] Burton-Wurster N, Zhang DW, Lust G. Arch Biochem Biophys. 316 (1995) 452-460.

[44] Richter H, Wendt C, Hormann H. Biol Chem Hoppe Seyler. 366 (1985) 509-514.

[45] Okada Y, Nakanishi I. FEBS Lett 249 (1989) 353-356.

[46] Shamamian P, Schwartz JD, Pocock BJ, Monea S, Whiting D, Marcus SG, Mignatti P. J Cell Physiol, 189 (2001)197-206.

[47] Zhu Y, Liu X, Skold CM, Wang H, Kohyama T, Wen FQ, Ertl R.F., Rennard S.I. Respir Res 2 (2001) 300-305.

[48] Doring G. Am J Respir Crit Care Med 150 (1994) S114-S117.

[49] Uehara A, Muramoto K, Takada H, Sugawara S. J Immunol 170 (2003) 5690-5696.

[50] Vered M, Simon S, Dearing R, Janoff A. Exp Lung Res 14 (1988) 167-183.

[51] Volpi N. Chem Biol Interact, 105 (1997) 157-167.

[52] Meddahi A, Lemdjabar H, Caruelle JP, Barritault D, Hornebeck W. Int J Biol Macromol 18 (1996) 141-145.

[53] Uitto J, Paul JL, Brockley K, Pearce RH, Clark JG. Lab Invest 49 (1983) 499-505.

[54] Rosenbloom J, Abrams WB, Mecham R. FASEB J 7 (1993) 1208-1218.

[55] Tixier JM, Godeau G, Robert AM, Hornebeck W. Biochem Pharmacol 33 (1984) 39333939. 
[56] Hornebeck W., Lafuma C., Robert L., Moczar M., Moczar E. Path. Res. Pract. 190 (1994) 895-902. 


\section{Legends of Figures}

Figure 1: Fucoidan inhibits proMMP-2 secretion. $72 \mathrm{kDa}$ gelatinolytic activities were detected by zymography (upper part), and immuno-detection of proMMP-2 by western blotting (bottom part) after 48 hours in culture media of serum deprived confluent dermal fibroblasts. a) IL-1 $\beta$ pre-incubation experiments. lane 1: control, lane 2: cell preincubation by IL-1 $\beta(100 \mathrm{U} / \mathrm{ml})$, lane 3: $10 \mu \mathrm{g} / \mathrm{ml}$ fucoidan, lane 4: $100 \mu \mathrm{g} / \mathrm{ml}$ fucoidan, lane 5: cell pre-treatment by IL-1 $\beta(100 \mathrm{U} / \mathrm{ml})$ before addition of $10 \mu \mathrm{g} / \mathrm{ml}$ fucoidan, lane 6: cell pre-treatment by IL-1 $\beta(100 \mathrm{U} / \mathrm{ml})$ before addition of $100 \mu \mathrm{g} / \mathrm{ml}$ fucoidan. b) IL-1 $\boldsymbol{\beta}$ continuous incubation experiments. lane 1 control, lane 2: IL-1 $(100 \mathrm{U} / \mathrm{ml})$ with 48 hours of continuous incubation, lane 3: co-incubation for $48 \mathrm{~h}$ of IL-1 $\beta(100 \mathrm{U} / \mathrm{ml})$ and $10 \mu \mathrm{g} / \mathrm{ml}$ fucoidan, lane 4: co-incubation for $48 \mathrm{~h}$ of IL-1 $\beta(100 \mathrm{U} / \mathrm{ml})$ and $100 \mu \mathrm{g} / \mathrm{ml}$ fucoidan. c) Quantitative analysis of 72kDa gelatinolytic activities. Analysis was performed on culture supernatants of 6 normal fibroblast strains by semi-automated image analysis expressed as grey level $\times$ surface of lysis band for 1000 cellules and referred to gelatinolytic activities of HT 1080 media. *** $\mathrm{P}<0.001, * * \mathrm{P}<0.01, * \mathrm{P}<0.05$ vs control without IL-1 $\beta,{ }^{\circ} \mathrm{P}<0.01$ vs control IL-1 $\beta$ pre-treatment, ${ }^{\Delta \Delta \Delta} \mathrm{P}<0.001$ vs control IL- $1 \beta$ continuous incubation.

Figure 2: Fucoidan inhibits proMMP-3 induction by IL-1 $\beta$. Immunodetection by western blotting of MMP-3 present in confluent dermal fibroblast supernatant a) IL-1 $\boldsymbol{\beta}$ preincubation experiments. lane 1: control, lane 2: cell pre-incubation by IL-1 $\beta(100 \mathrm{U} / \mathrm{ml})$, lane 3: $10 \mu \mathrm{g} / \mathrm{ml}$ fucoidan, lane 4: $100 \mu \mathrm{g} / \mathrm{ml}$ fucoidan, lane 5: cell pretreatment by IL-1 $\beta$ (100 U/ml) before addition of $10 \mu \mathrm{g} / \mathrm{ml}$ fucoidan, lane 6: cell pretreatment by IL-1 $\beta$ (100 $\mathrm{U} / \mathrm{ml}$ ) before addition of $100 \mu \mathrm{g} / \mathrm{ml}$ fucoidan. b) IL-1 $\boldsymbol{\beta}$ continuous incubation experiments. lane 1: control, lane 2: IL-1 $\beta(100 \mathrm{U} / \mathrm{ml})$ continuous incubation, lane 3: co-incubation for 
$48 \mathrm{~h}$ with IL-1 $\beta(100 \mathrm{U} / \mathrm{ml})$ and $10 \mu \mathrm{g} / \mathrm{ml}$ fucoidan. lane 4: co-incubation for $48 \mathrm{~h}$ with IL$1 \beta(100 \mathrm{U} / \mathrm{ml})$ and $100 \mu \mathrm{g} / \mathrm{ml}$ fucoidan.

Figure 3: Fucoidan increases MMP-2 complex formation. Immunodetection by western blotting of free and complex forms of MMP-2: a) Effect of fucoidan alone. lane 1: control, lane 2: $10 \mu \mathrm{g} / \mathrm{ml}$ fucoidan, lane 3: $100 \mu \mathrm{g} / \mathrm{ml}$ fucoidan. b) Effect of fucoidan in IL-1 $\boldsymbol{\beta}$ continuous incubation experiments. lane 1: IL-1 $\beta(100 \mathrm{U} / \mathrm{ml})$ for 48 hours of continuous incubation, lane 2: co-incubation for $48 \mathrm{~h}$ of $\mathrm{IL}-1 \beta(100 \mathrm{U} / \mathrm{ml})$ and $10 \mu \mathrm{g} / \mathrm{ml}$ fucoidan, lane 3: co-incubation for $48 \mathrm{~h}$ with IL- $1 \beta(100 \mathrm{U} / \mathrm{ml})$ and $100 \mu \mathrm{g} / \mathrm{ml}$ fucoidan. c) Effectiveness of MMP-2 complex formation. MMP-2 complex formation was measured $(n=2)$ in presence or absence of 10 or $100 \mu \mathrm{g} / \mathrm{ml}$ fucoidan, without IL- $1 \beta$, after IL- $1 \beta$ pre-treatment or IL-1 $\beta$ continuous incubation experiments.

Figure 4: Fucoidan enhances TIMP-1 complex formation. a) Immunodetection by western blotting of free and complex forms of TIMP-1 secreted in confluent dermal fibroblast media. lane 1: control, lane 2: $100 \mu \mathrm{g} / \mathrm{ml}$ fucoidan, lane 3: $100 \mu \mathrm{g} / \mathrm{ml}$ fucoidan, b) Quantification of free TIMP-1 and effectiveness of TIMP-1 complex formation with fucoidan treatments $(\mathrm{n}=5)$.

Figure 5: Fucoidan inhibits dermal elastic fibers hydrolysis mediated by HLE (histologic sections). Mid dermal elastic fibers serial sections (a,b,c,d): a) control, b) $\operatorname{HLE}(5 \mu \mathrm{g})$, c) HLE $(5 \mu \mathrm{g})$ with fucoidan $(10 \mu \mathrm{g} / \mathrm{ml})$, d) HLE $(5 \mu \mathrm{g})$ with fucoidan $(100 \mu \mathrm{g} / \mathrm{ml})$. Mid dermal serial sections of arteriole (e,f,g,h): e) control, f) HLE $(2 \mu \mathrm{g})$, g) HLE $(2 \mu \mathrm{g})$ with fucoidan $(1 \mu \mathrm{g} / \mathrm{ml})$ h) HLE $(2 \mu \mathrm{g})$ with fucoidan $(100 \mu \mathrm{g} / \mathrm{ml})$. Ep: epithelium, Ox: Oxytalan fibers, Ela: elaunin fibers, EF: Elastic fibers, Lu: Lumina, EL: Elastic lamellas, Magnification: $\times 150$. 
Figure 6: Fucoidan inhibits HLE action on dermal elastic fibers hydrolysis (Quantitative image analysis). Quantification of AA\% occupied by elastic fibers was performed in serial human skin sections. Control section (white), enzymized section with 2 or $5 \mu \mathrm{g}$ of HLE (black), enzymised section with HLE ( 2 or $5 \mu \mathrm{g}$ ) incubated with fucoidan at $1 \mu \mathrm{g} / \mathrm{ml}$ (deep grey), enzymized section with HLE ( 2 or $5 \mu \mathrm{g}$ ) incubated with fucoidan at $100 \mu \mathrm{g} / \mathrm{ml}$ (grey). Statistical analysis was performed on results obtained with six sections (6 fields measured for each section): Enzymized skin elastic fibers area fraction vs control elastic fibers area fraction, $* *: p<0.01 ; * * *: p<0.001$

Figure 7: Fucoidan protects dermal elastic fibers against HLE action. a) control of mid dermal elastic serial sections, b) HLE $(2 \mu \mathrm{g})$, c) pre-incubated section with fucoidan $(10 \mu \mathrm{g} / \mathrm{ml})$ before wash and incubation with $\operatorname{HLE}(2 \mu \mathrm{g})$; d) pre-incubated section with fucoidan $(100 \mu \mathrm{g} / \mathrm{ml})$ before wash and incubation with HLE $(2 \mu \mathrm{g})$. Ep: epithelium, Ox: Oxytalan fibers, EF: Elastic fibers, Magnification: $\times 150$. 
Table 1: Effect of fucoidan on total gelatinase A secretion

\begin{tabular}{|l|c|c|}
\cline { 2 - 3 } \multicolumn{1}{c|}{} & ng for $10^{5}$ cells & sdm \\
\hline Control & 21,65 & 6,0 \\
\hline Fucoidan $(10 \mu \mathrm{g} / \mathrm{ml})$ & 4,22 & 2,4 \\
\hline Fucoidan $(100 \mu \mathrm{g} / \mathrm{ml}$ & 7,02 & 3,1 \\
\hline
\end{tabular}




\section{Figure 1}

a) ProMMP-2 secretion after IL-1 $\beta$ pre-incubation

IL-1 $\beta(100 \mathrm{U} / \mathrm{ml})$

Fucoidan $(10 \mu \mathrm{g} / \mathrm{ml})$

Fucoidan $(100 \mu \mathrm{g} / \mathrm{ml})$

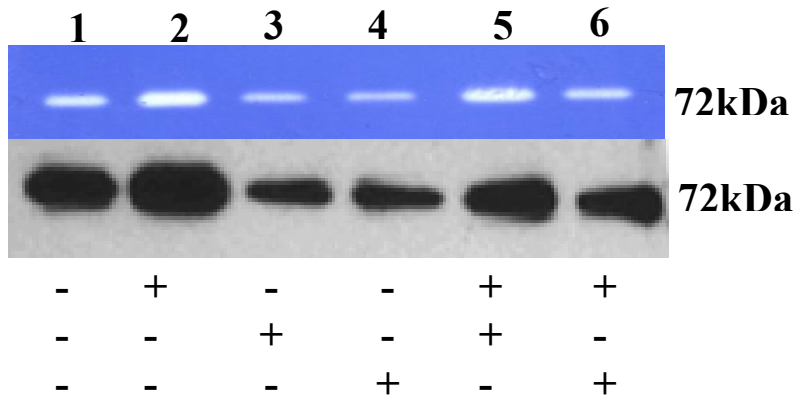

b) ProMMP-2 secretion with IL-1 $\beta$ continuous incubation

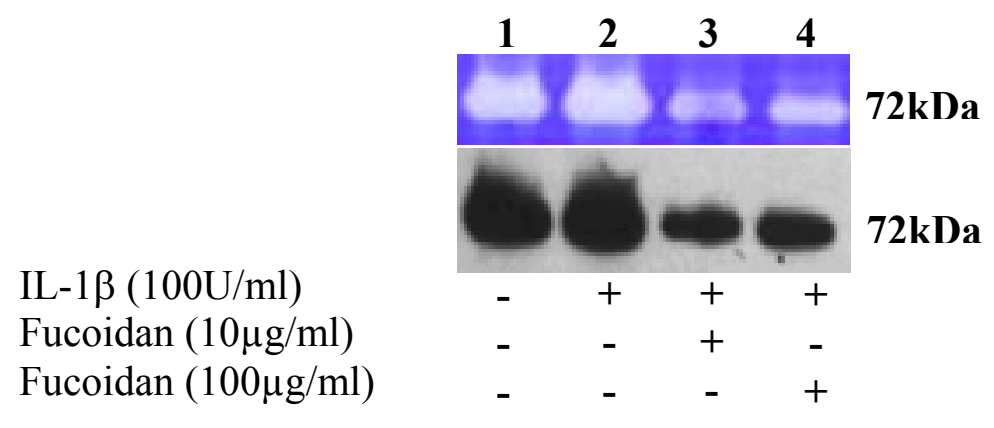

c) Quantification of proMMP-2 gelatinolytic activities

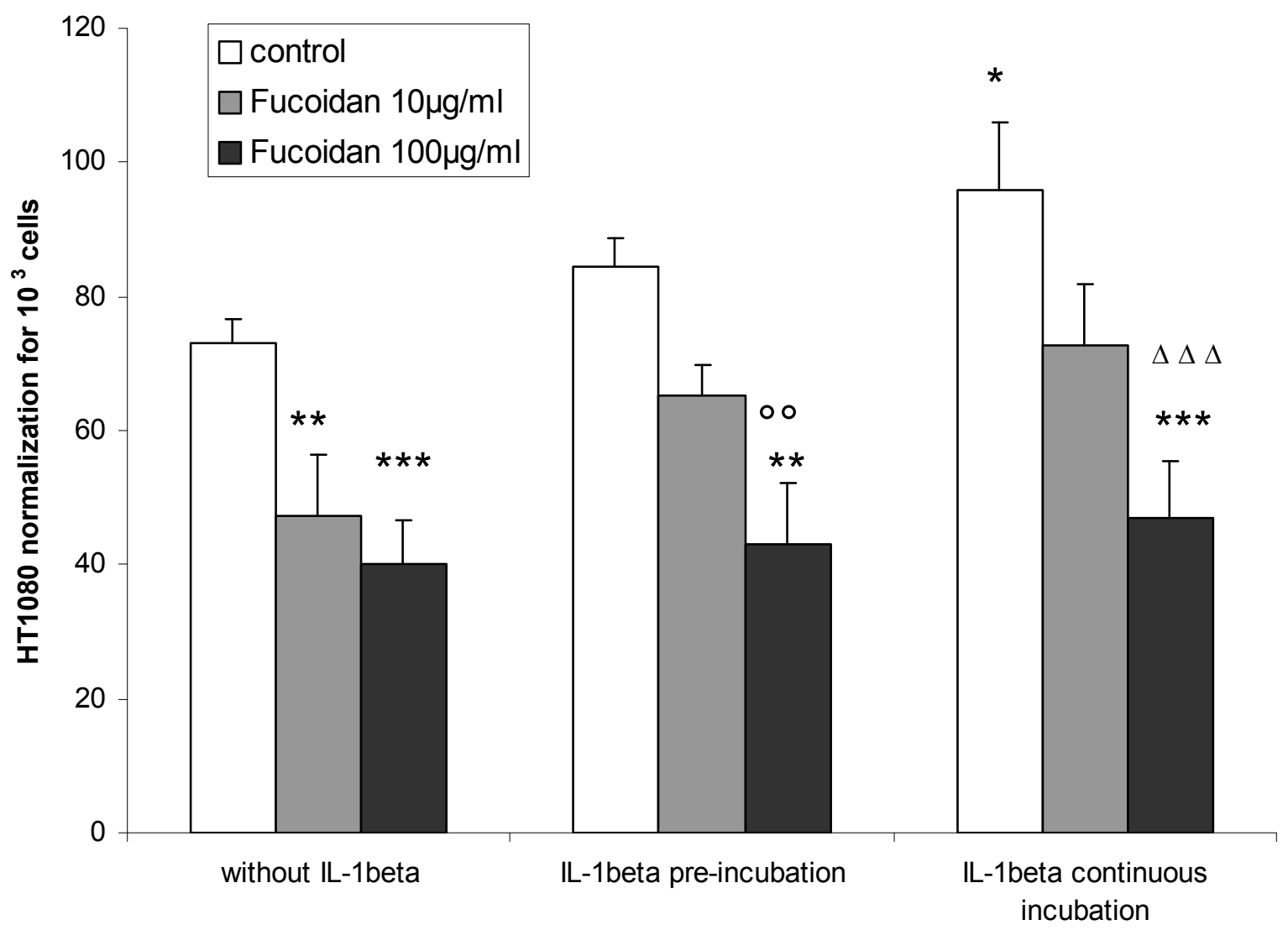




\section{Figure 2}

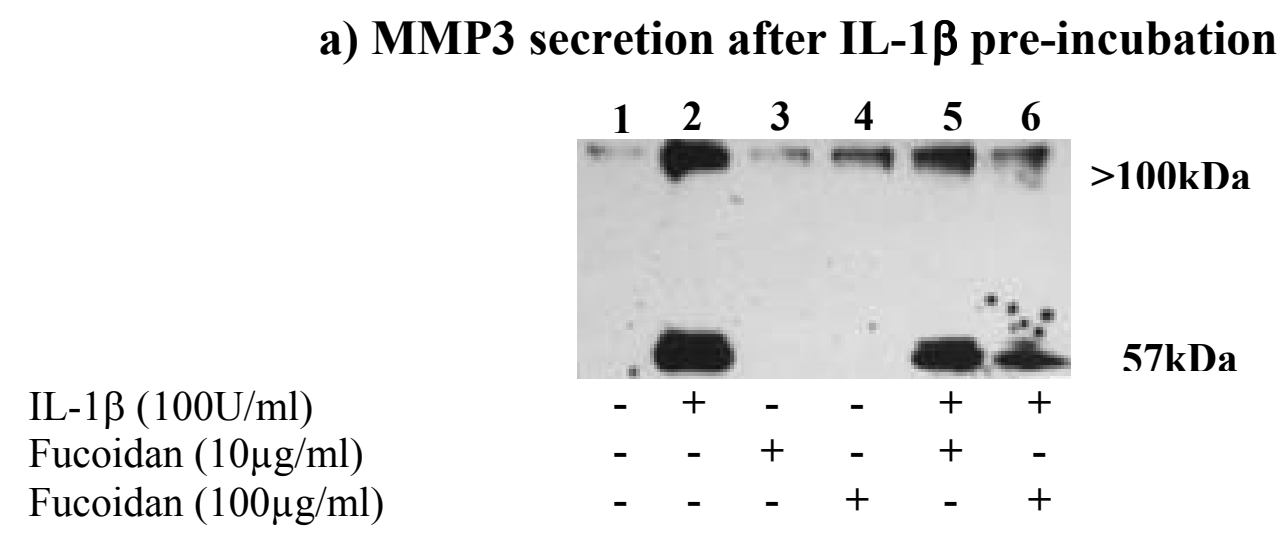

b) MMP3 secretion with IL-1 $\beta$ continuous incubation

IL-1 $\beta(100 \mathrm{U} / \mathrm{ml})$

Fucoidan $(10 \mu \mathrm{g} / \mathrm{ml})$

Fucoidan $(100 \mu \mathrm{g} / \mathrm{ml})$

$\begin{array}{llllll}1 & 2 & 3 & 4 & \\ & & & - & 57 k D a \\ - & + & + & + & \\ - & - & + & - & \\ - & - & - & + & \end{array}$


Figure 3

a) Free and complex forms of MMP-2

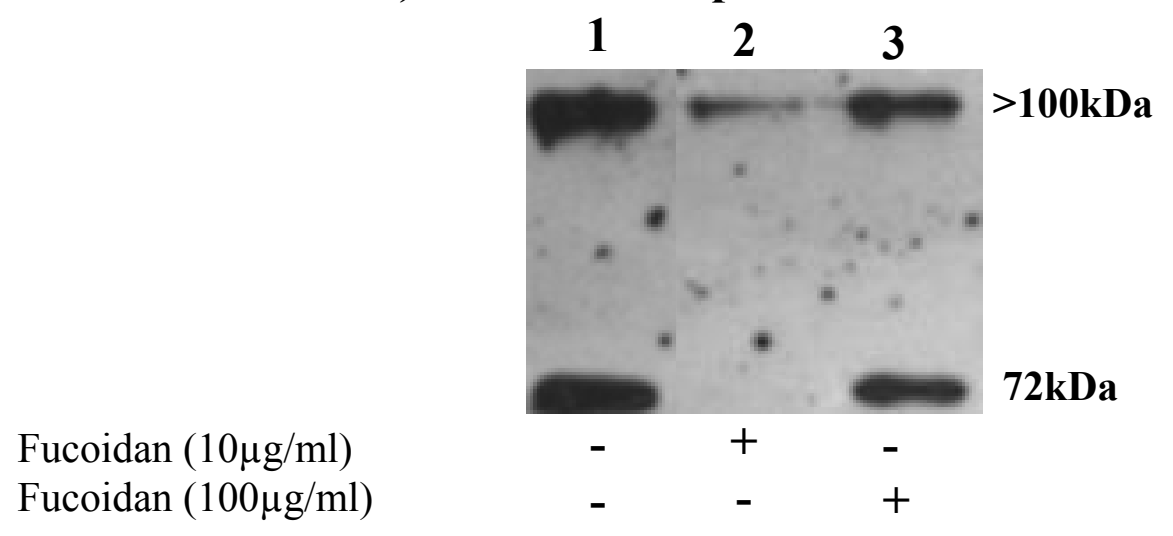

IL-1 $\beta(100 \mathrm{U} / \mathrm{ml})$

Fucoidan $(10 \mu \mathrm{g} / \mathrm{ml})$

Fucoidan $(100 \mu \mathrm{g} / \mathrm{ml})$

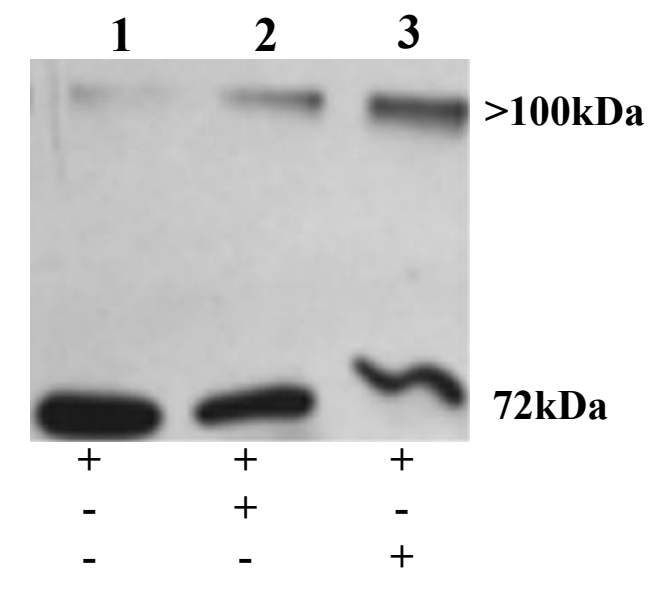

c) MMP-2 complex formation (100kDa)

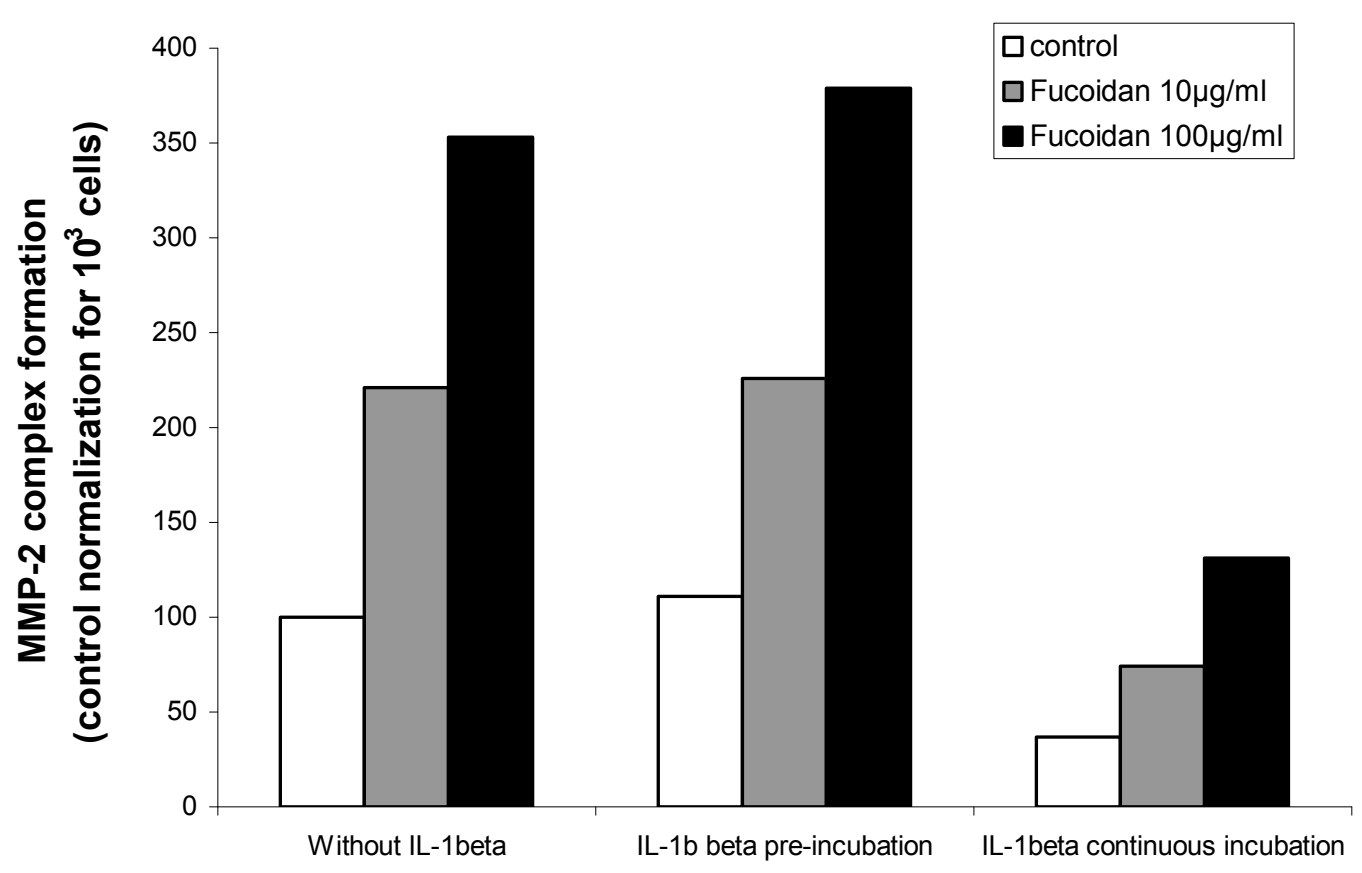


Figure 4

a) Free and complex forms of TIMP-1

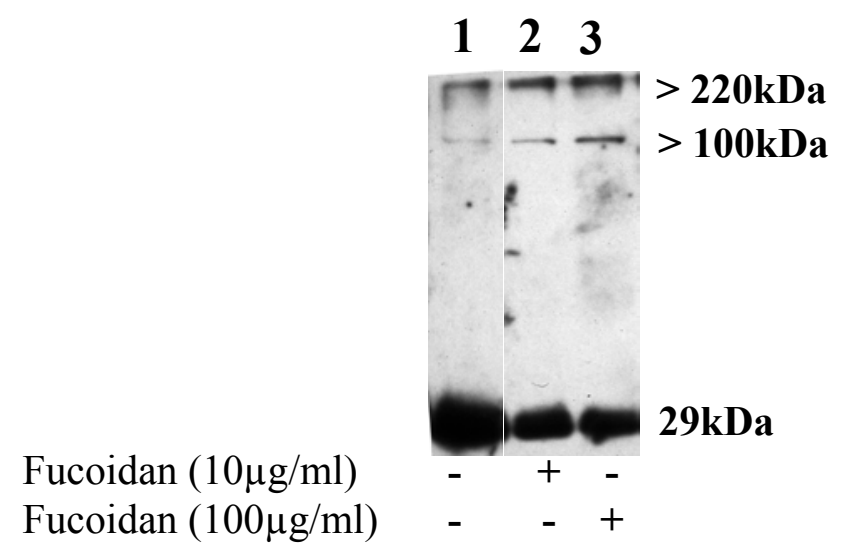

b) Free TIMP-1 secretion and complex formation

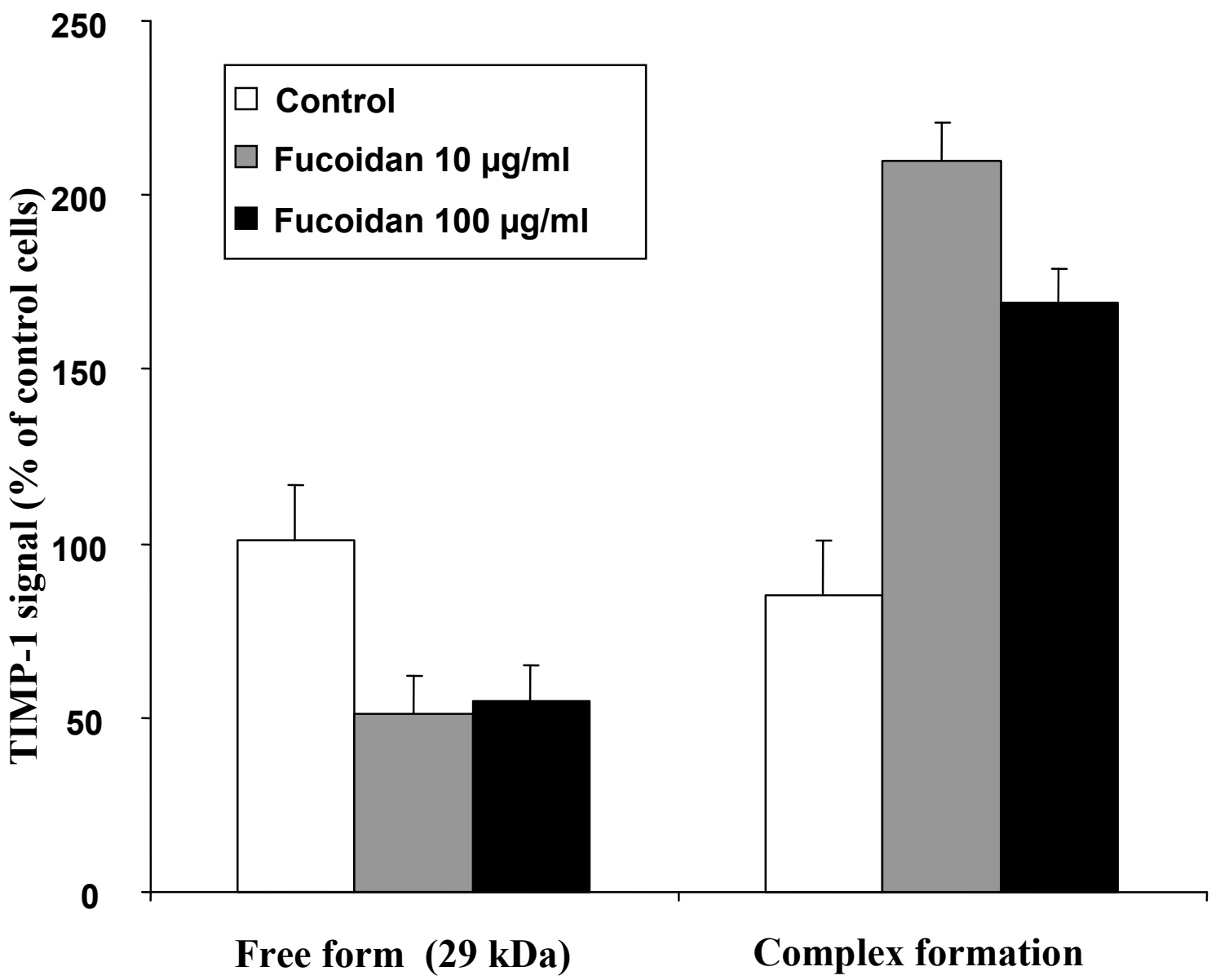




\section{Figure 5}

\section{Inhibition of leukocyte elastase}

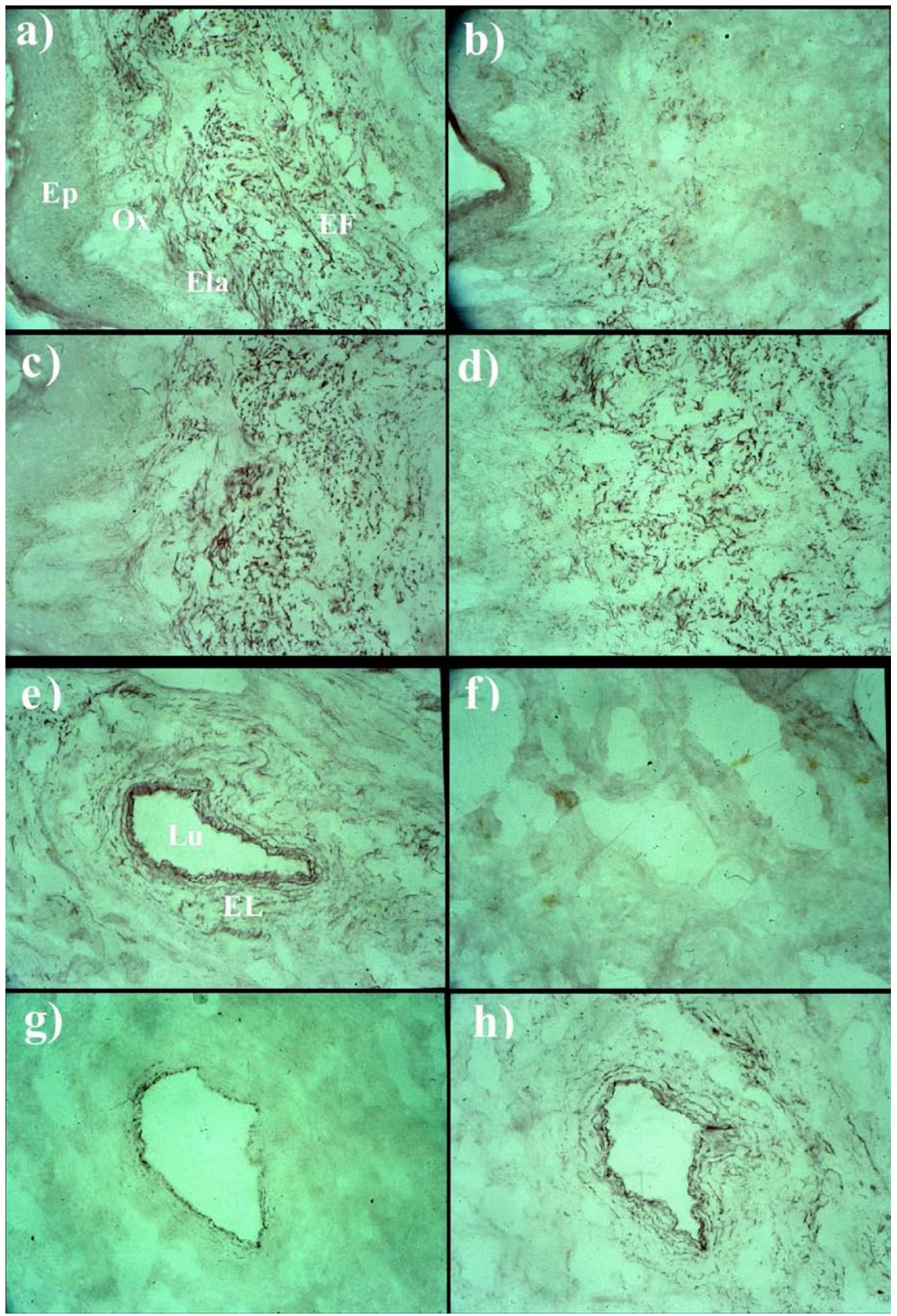


Figure 6

Quantification of skin elastic fibers area fraction

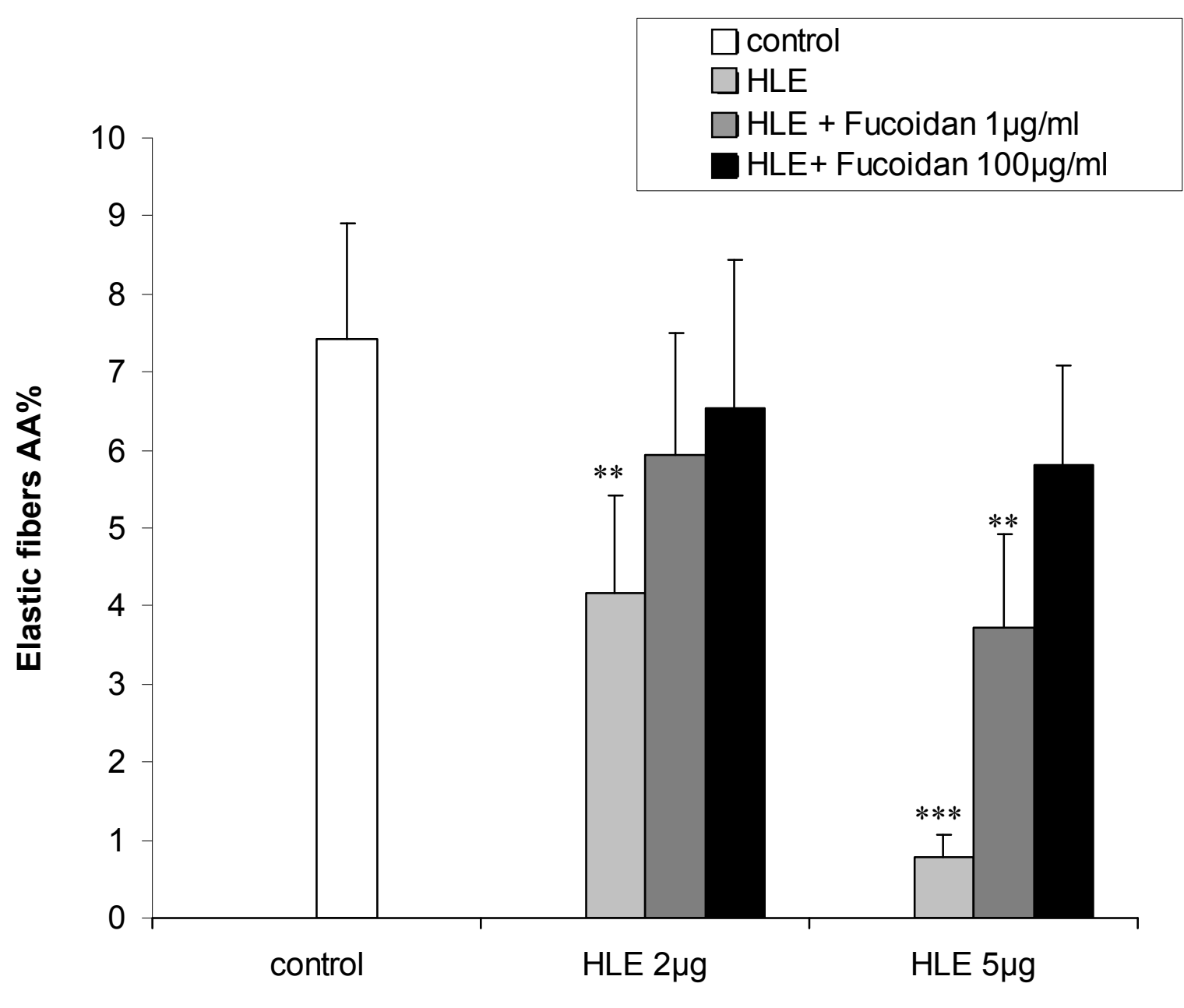




\section{Figure 7}

Skin elastic fibers protection against proteolysis

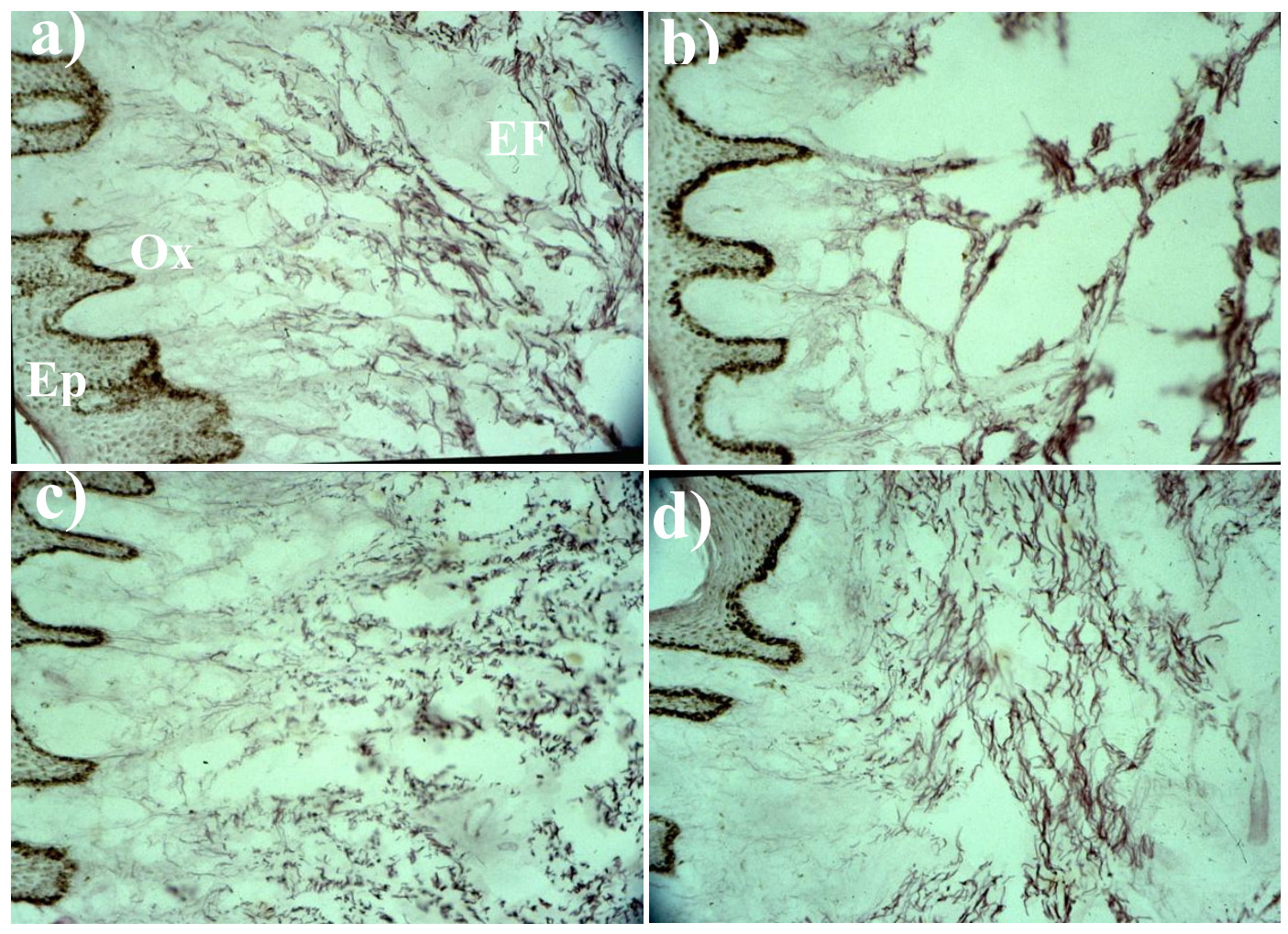




